\title{
What Does Public Art Teach Us? \\ Public Art, Public Pedagogy and Community Participation in Making
}

Debbie Qadri

Victoria University

\begin{abstract}
What does public art teach us? Although the meaning of any artwork is not directly received but instead refracted by people's personal responses, experiences and understandings, it can be argued that the artwork plays a pedagogical role. Public art teaches us in two ways, firstly, through the narratives and knowledge it projects and secondly, through its authorship and placement it teaches us who has the right and the power to place art in public space. Furthermore in the instance of permanent public art, duration and time endorse, and normalise these narratives and pedagogical meanings. This article utilises this perspective to explore how community involvement in the making of permanent public art might create a different type of pedagogy through providing opportunities to offer other narratives to its audience and a more democratic alternative to the authorship of art in public space. Within the concept of cultural democracy, these artworks not only enable community members to individually express themselves in public space, but also to collaboratively produce meaning and knowledge in public space.
\end{abstract}

\section{Keywords}

public art, community art, public pedgogy, cultural democracy

Journal of Public Pedagogies, Number 1, 2016

Published by Public Pedagogies Institute: www.publicpedagogies.net.au Open Access article distributed under a CC-BY-NC 4.0 license

URL http://jpp.vu.edu.au/

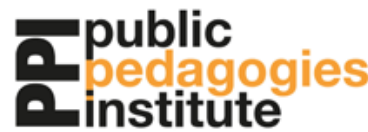


This article explores the idea that permanent public art has a pedagogical role and that this exists in two areas: the subject matter and narratives offered by the artwork, and also a pedagogy about whose role it is to facilitate, author and place artwork in public space (e.g. commissioners, artists, community?). I raise concerns about the pedagogical meaning of permanent public art and the inclusion or exclusion of different genres of art in its discourse. Community involvement in making permanent public art is a practice that invokes cultural democracy both in the process of making the work and the physical outcome of the art object. It has a capacity for creating different types of pedagogy, through providing other narratives. This perspective stems from my experience as an artist who has worked with community groups and schools to make permanent public artworks for many years, and also voices my concern for the need for research in this area which brings together theory of community participation in making art with that of 'permanent public art'. There is a lack of research into the practice of community participation in making permanent public artwork, its meaning, outcomes and pedagogy. There is more to learn about how community participation in making contributes to our understanding of public art and what we learn in public spaces.

\section{What is Public Art?}

The term 'public art' is leashed in a strange space between the art world, architecture and landscape. It can be broadly defined as permanent or temporary artworks on sites that have open public access and are located outside museums and galleries (Zebracki 2011). In Western culture public art became popular in the late twentieth century following the memorial movement after the First World War (Holsworth 2015), and its advent as art and use as political ideography (Miles 1997) after the Second World War (Zebracki 2011). This is evidenced in the host of memorials and artworks that were erected all over the world to commemorate lost lives and to confirm national political ideology, including democracy and communism. In the USA in 1967, the creation of the National Endowment for the Arts, Art in Public Places program is cited as the probable beginnings of public art as we know it today (Cartiere $\&$ Willis 2008). In Australia public art commissioning has become largely the domain of local councils and the few organisations that manage public spaces such as roads and waterways, and generally refers to artworks that are officially placed in public space (Cartiere \& Willis 2008, Fazakerley 2008).

Public art also claims many roles and functions-and these are largely devised by the planners and creators of public art, and rarely the public (Zebracki 2013). Its purposes include; urban revitalisation (Pollock \& Sharp 2012), economic development (Schuermans et al., 2012), the attraction of tourists and investors to the area (Schuermans et al., 2012), social benefits such as civic pride, social interaction, a sense of community and local identity (Schuermans et al. 2012) or the public good (Holsworth 2015). These ideas are evident in many council and government policies and guidelines. Also evident in many policies is a growing trend to justify funding of permanent public art, in terms of economics and industry (Creative Victoria 2016). Keeping in mind that public art has its origins in ideological purposes, that of consolidating a particular version of history and a set of values, and many of these works are permanent and remain prominent in our urban landscapes and part of our heritage, we might well ask what is the ideological purpose of public art now?

Often traditional ideas about art objects are part of public art discourse (Gablik 1995), for example public artworks are often celebrated as the works of renowned artists and as part of a city's public art collection (for a good example of this read the Auckland City Council Public Art Policy 2008). Public art generally differs from an artist's studio practice because it is caught in a web of stakeholders, being formed by committees, the needs and 
desires of individuals in positions of power to commission it, and the pressure to engage or consult with the local community. Far from working in a traditional autonomous art practice, artists working in public space have multiple and often complex roles (Phillips 1995). The artists who work on commissions need to work in collaboration with architects, engineers and a committee and their work is made to serve a specific purpose, which has left the idea of 'public art practice' open to much criticism (Holsworth 2015). It is very difficult, if not impossible, to develop a legal art practice through which you can work and develop your ideas in public space.

\section{My Experience of Community Participation}

I am situated in my research by my practice as an artist who works with communities to make permanent artworks out of hand-made ceramics and mosaic. I work mostly with schools and kindergartens to make artworks where everyone contributes to the making, and in these settings this collaborative process seems a common-sense and natural thing to do. I also initiate my own collaborative art projects with communities which attempt to document a broad range of experiences, values and stories. But I rarely have the opportunity to do these sorts of works on a larger scale or outside of educational environments.

I derive the meaning of making permanent artworks with communities from the initial reasons offered by those who employ me, my experiences with the community during the making of the work, and the feedback I recieve afterwards. I have experienced this type of collaboration as a powerful way of developing and expressing community ownership, values and identity. From this experience I see two functions emerging: on one hand it pays attention to, and represents individuals and diversity, but at the same time through the collaborative process of making the art, it develops and celebrates 'community'. These polarities of the individual and the community are both represented.

\section{Community Engagement and Public Art}

The focus on community participation in cultural initiatives is increasingly on the agenda in arts funding guidelines and policy (Zebracki 2011). There is an interest in how participating in arts and cultural activity intersects with other areas of public concern including education, health and well-being, community identity and development (Stage Two Report, Social Impacts of Participation in the Arts and Cultural Activities, Commonwealth of Australia, 2005). This interest in participation, community identity and ownership of public space is also evident in many documents such as guidelines, statements and policies, of local councils and national and state art departments and organisations (Pollock and Sharp 2012). However, there seems to be a differentiation, that regards community participation as useful in ephemeral projects and activities but not appropriate for larger permanent public art commissions. Larger public art commissions usually include community consultation, but not participation in making the artwork. In actuality, many examples of small scale permanent projects exist that involve community members as makers. These projects can be found in parks, schools and community centres, but are rarely described as public artworks, recorded on council websites as part of their public art collection, entered into the history of public artworks, or documented and theorised in academic literature.

My argument and research, however, is more interested in why and how community-made permanent public artworks are absent from the discourse about public art, and when community making is included in this discourse, it is relegated to the ephemeral, temporary or short term projects. The term 'community art' provides a way to 'catch' community par- 
ticipation as a good 'process' and to ignore the value and phenomenon of community participating in making permanent public art objects.

Unfortunately most theorising of community participation in making does not address concepts of permanence and what this means, nor the pedagogical roles of the work both as process and end product. My research explores permanent public artworks made by community within the discourse of permanent public art. This is important because we need to explore what community participation in making permanent public artwork can offer and contribute to our understanding of public art and what we learn in public spaces.

\section{Current Theorising of 'Participation'}

In Western art culture there is a current push for participation in both local government and institutional arts policies (Pollock \& Sharp 2012, Melbourne City Council 2015). At the same time there is a parallel turning towards the audience and participation, by some areas of contemporary art practice. These approaches which emerged from the 1990's onwards are described in various conceptual frameworks include: The Social Turn (Bishop 2006, Boros 2011), New Genre Public Art (Lacy 1995), Relational Aesthetics (Bourriaud,1998) Dialogical Aesthetics (Kester 2005) Dialogue-based Public Art (Finkelpearl, 2000), New Situationism (Doherty, 2015) or Spatial Aesthetics (Papastergiadis 2006). These theoretical stances share a common interest in process, using public space and the involvement of the audience or public as part of the work. With the emphasis on participation and the de-emphasis of object-based work (Jacob 1995) this philosophy champions community participation but it tends not to include permanent public art. Both Kate Crehan (2011) and Mark Dawes (2008) discuss the impact of community involvement in making as an alternative to consultation, but neither refer to permanent artworks. There are many case studies and reports of ephemeral participatory public artworks (Lacy 1995, Bishop 2006, Beyes 2010) but very few about permanent works made by communities.

Claire Bishop (2006) asserts that both governmental policy on participation and the new social art use the same rhetoric. Joanne Sharp (2007) agrees that public art's use of participation as a tool for urban renewal 'reflects the influence of "new genre public art" approaches which privilege art as process over art as product' (p.274). But Pollock and Sharp (2012) express their concerns about the rhetoric of participation, pointing out that through processes of consultation and token 'participation', communities may become increasingly aware of their powerlessness to affect their environment. According to Arnstein (1969) consultation is ranked as tokenism.

Paul O'Neill (2010) suggests that although participatory art does not often place emphasis on the end product, it is this end product which is often documented, written about and experienced. This dilemma of object versus process, as explicated in contemporary participatory movements, remains an area that needs further interrogation, particularly since participatory practice, more often than not, leads to ephemeral or short-lived works, and permanent artworks tend to involve consultation or participation in design of the artwork, but not actual participation in the making. It's like there is a divide, an imaginary sweeper that relegates the artwork as either a permanent public artwork or a participatory non-permanent object. If the artwork is both community made and permanent public, then it becomes called 'community art', not 'public art'.

This (perhaps unintentional) act of making community made artworks into 'not public art,' also makes them less important and powerful. Firstly it takes people out of the equation as possible makers of the permanent or durational visual imaginary in their public space and secondly, it informs us that un-trained or un-professionals can't make art that's worthy of 
being permanent in public space. If they do participate in a community made artwork, this is referred to as 'community art' instead of 'public art'. Little choice remains if you do want to make your mark in public space, except to do it illegally. As Halsey and Young suggest: 'Increasingly, the ability to "legitimately" (that is, legally) leave one's mark is becoming directly related to one's capacity to buy or rent space' (2002, p. 180).

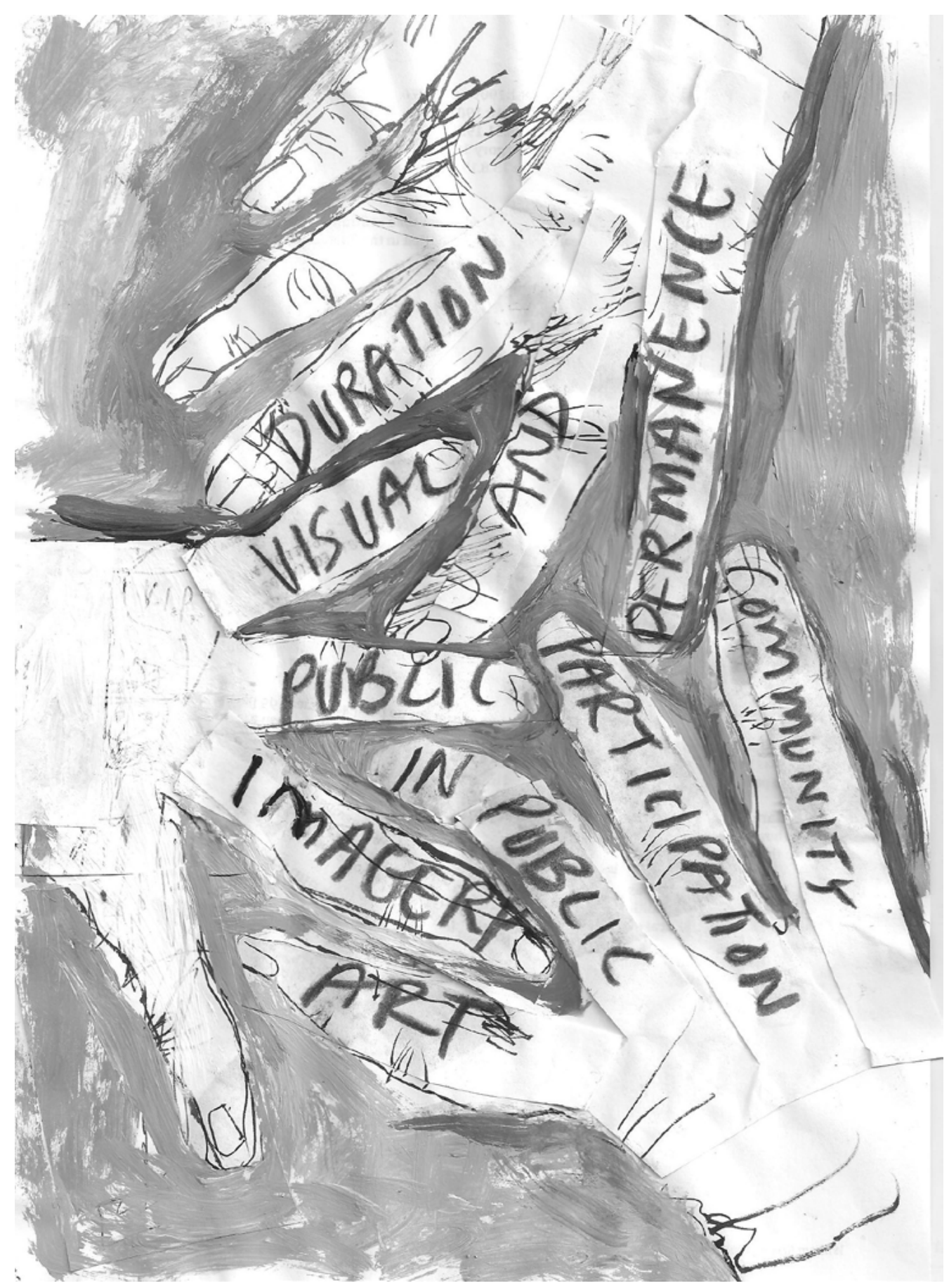

Figure 1: Intermeshing, Debbie Qadri, 2016 


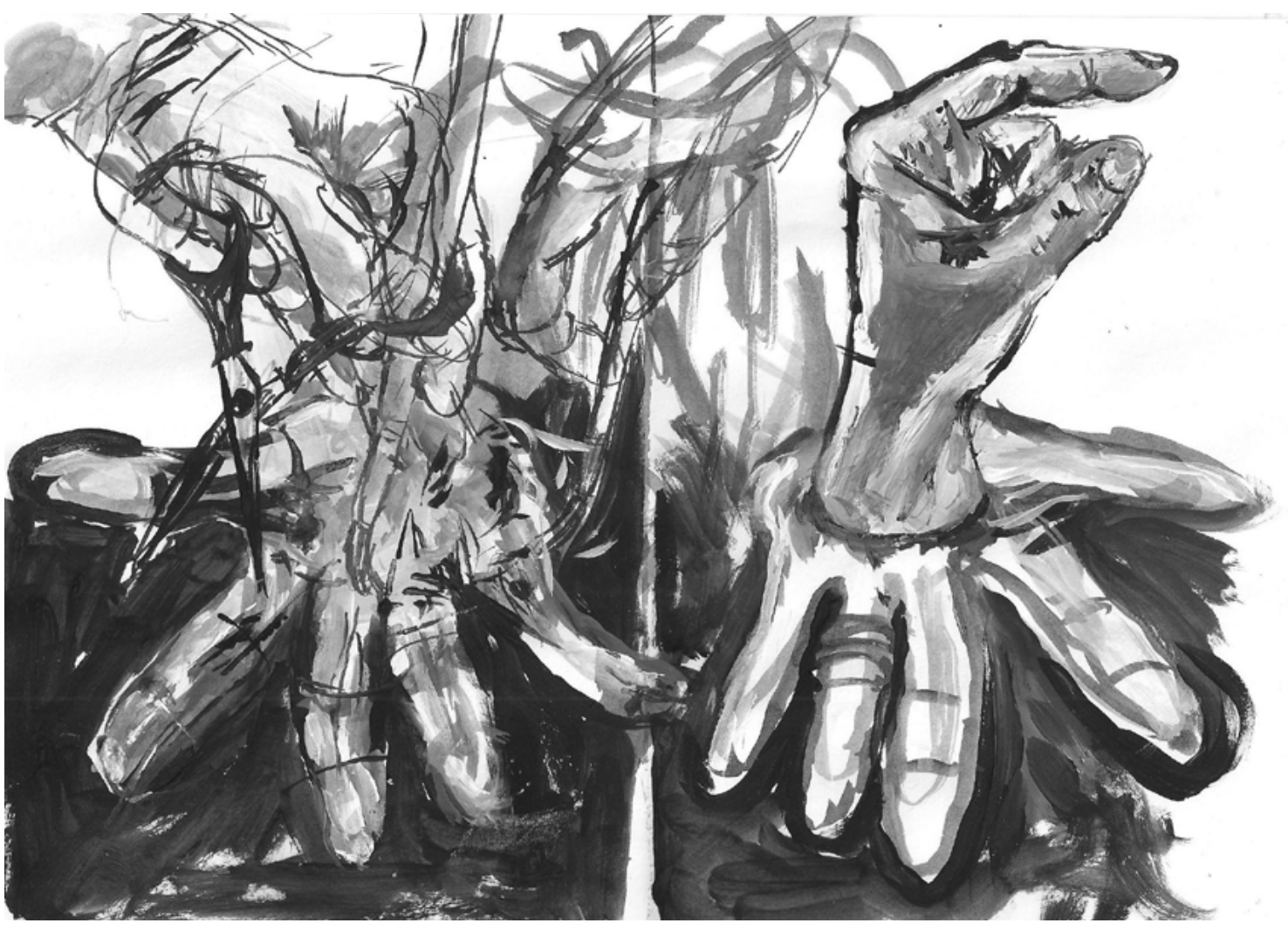

Figure 2: The Two-Fold Action Of The Artwork, Debbie Quadri, 2016. On the one hand it creates meaning whilst being made by a community and on the other, it creates a second stage of meaning as a permanent artwork in public space (Quadri 2016).

\section{Public Pedagogy}

Public art creates knowledge and learning in public space, and it can challenge or confirm particular cultural narratives. The audience may choose to receive these ideas or not. The idea of public pedagogy offers a position from which to speculate about the role of public art. In this paper I am focusing on the intermeshing of three things: 1) visual public imagery and how permanence and duration add power to the artwork and its means of conveying messages to more people, 2) community participation in making, and 3) the concepts of public pedagogy and cultural democracy.

But after the work is made in public space it takes on yet another life of its own in which new meaning is developed by the audience. I am very interested in this two-fold action of the artwork. On one hand it creates meaning whilst being made by a community and then on the other, it creates a second stage of meaning as a permanent artwork in public space.

\section{Communication}

Despite the intentions of its commissioners and makers, art objects say different things to different people and it is difficult to generalise how and what they say. Particular to art is its openness to interpretation. We cannot all experience art in the same way-its meanings are refracted by our own experiences and understandings. Each person's interpretation and response to an artwork is different and may not be even knowable to themselves. When we approach an artwork we may have no inkling of its history and purpose. Without its context what can the artwork tell us? What knowledge and understanding does it impart to the audi- 
ence? How is an object absorbed and its meanings transferred? Schuermans, Loopmans and Vandenabeele suggest there is a problem in that 'the actual agency of public art-that what happens when art is 'out there' in public space-is barely understood' (2012, p. 676). Even in the absence of answers it is important that we consider these questions. Michel de Certeau (1988) suggests we are not just consumers, instead we pick and choose, adjust and manipulate things-we are users. He is interested in the 'secondary production', how those who are not the makers, use the image (Certeau 1988, p. xiv). This has to be kept in the back of our minds, that though the purposes of making particular public artworks might be identified, this does not prescribe their meaning after they are placed into public space.

The artwork has a communication advantage when it is made by a local community as it means they can develop the meaning of the work and create dialogue about the work as they are making it. Afterwards, when the work sits in public space, there is a contextual dialogue already circulating about the meaning and making of the work and how this is couched in the artwork's location.

\section{Broadened Definitions}

When we talk about public art, we tend to think about official and sanctioned public art that gets commissioned and installed by those who are in a position of power and have the responsibility of placing art in public space. In many public art policies written by councils the definition of public art is quite clearly articulated as only commissioned and permissioned work. This is the type of definition often found in guidelines and policies, so that the term 'public art' becomes defined by the official bodies that make it. It creates a circular turn, like a snake eating its own tail, a creature that doesn't need to consider the outside world when it has its own tail to eat.

Graffiti is often clearly discussed as 'not public art'. However, a broader definition of public art would consider how permanent commissioned public art sits within the wider field of art practices that occur in public space (such as community art and interventions). Much of this practice is not brought into the same contexts as the official 'public art' but nevertheless is public art and has a strong relationship with official versions of public art. Permanent public art is not placed into public space without the knowledge or effects of these other genres. For example, when a permanent public artwork is commissioned, graffiti is acknowledged and included in the process as the designers propose how the artwork will withstand or avoid being vandalised by graffiti.

Other forms of art in public space, though illegal or un-commissioned, reside in the same spaces and are often made using the same materials. However, the discourse of public art shouldn't differentiate commissioned work from street art, graffiti, tagging, throw ups, craftivism, guerrilla kindness, murals, artworks by community members, ephemeral works and the visual imagery of advertising. These genres are sometimes utilised in permanent public art commissioning, for example a mural might be spray painted or yarn-bombers hired by a council to decorate an area, or craftivists commissioned to make community engaged ephemeral artworks. There is a fluid interaction with different genres moving in and out of the public space over time (and into permission, commission, intervention and illegality). I see this as a push and pull scenario, as a space of tension and interaction where permanent public art might sit importantly in the middle (as it is the official art of public space) but be tugged to and fro by the other genres around it. Commissioned permanent public art could be perceived as the most powerful player, if budget, size and duration give an artwork more power to make meaning for itself, but its adversaries are plentiful and resilient and often offer more compelling politics or narratives. 
We often witness perforations and permutations of these separate categories, for example when a street art mural becomes permanent (Keith Haring Mural, Collingwood, Melbourne) or when artworks made by communities are large, permanent and public (The Tree Project, Vicotria, The Great Wall of St Kilda, Melbourne). Some artworks are considered important to retain and have been in prominent positions for decades or centuries, whilst others, more fleeting (like graffiti), may present strong visual imagery because of their persistence in repetition and claiming short-lived but great amounts of physical space. Literature on public art usually addresses one particular field of art in public space with little reference to the others and this wider web of practice is rarely considered as a whole. There is an opportunity for more attention to be given to the interaction between these fields or genres in public space and how they interact.

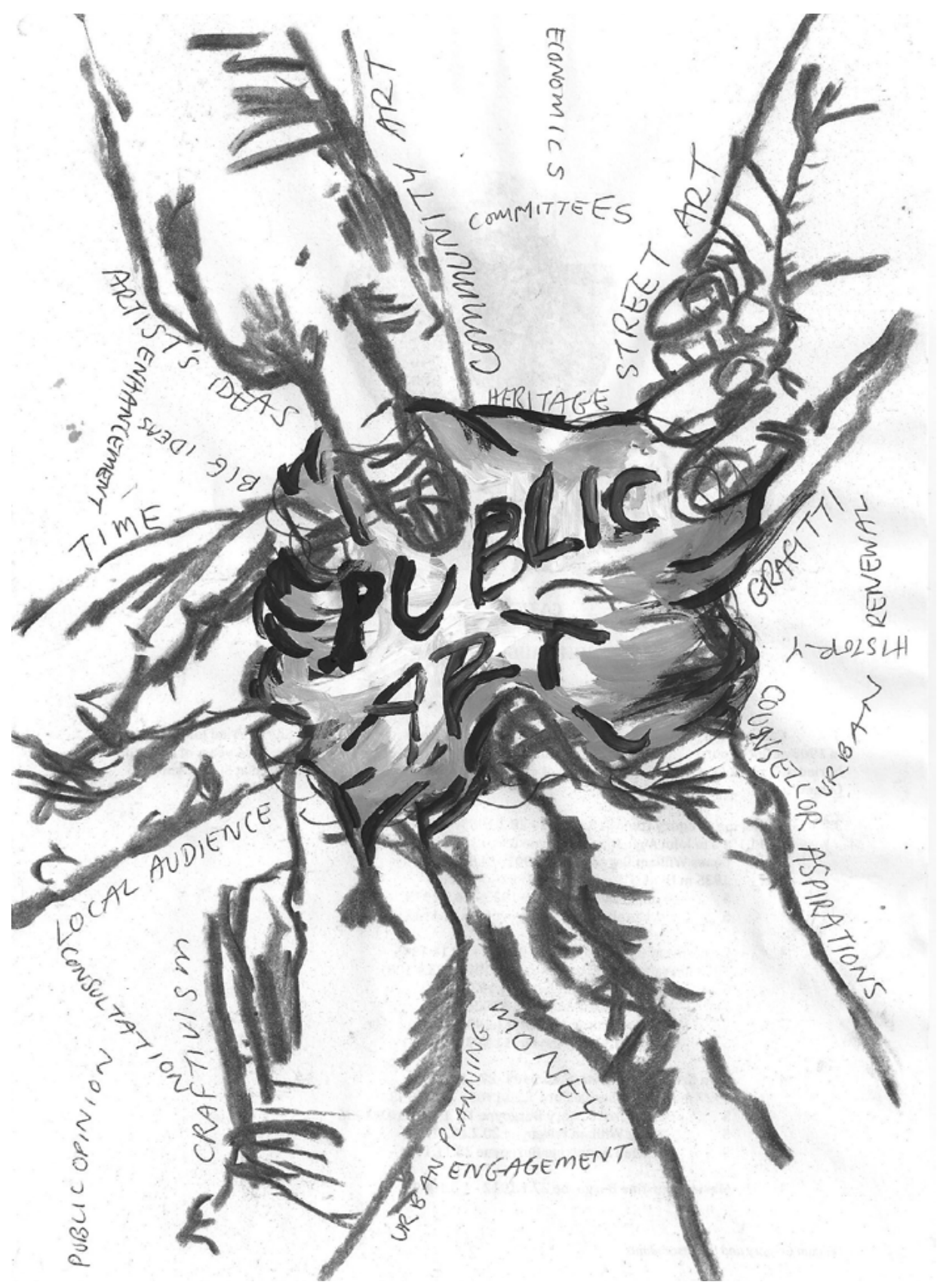

Figure 3: Public Art, Debbie Quadri 2016 


\section{Public Art and Cultural Democracy?}

My perspective of community participation in making permanent public art is as a positive action for delivering meaning under the flag of cultural democracy. Involving people in the making is a step towards ensuring that the meaning of the work resonates with a larger group of people, and creates an opportunity for dialogue created by the work to move into the local community. Not always but often, community made artworks include 'others', they make visual the narratives and meanings that are often absent from this landscape and enable the spirit of positive discrimination. Most importantly, they have the capacity to do this.

If you approach public art through the perspectives of critical theory, feminism or post-colonial theory, you can find many things to criticise about public art, particularly in its early twentieth century appearance as memorials to great men, events and role in support of political agendas. It has been argued that public art has the ability to communicate ideology. Permanent artworks are powerful because they 'endure' over long periods of time and can create, inform and shape narratives of history and culture. Public art plays a role in informal education as a form of public pedagogy, particularly in its enactment of citizenship within public space and as an educative arena in which norms of public space and dominant social discourse are challenged (Sandlin et al.2005).

Patricia Phillips claims that public art's position outside general art history, provides it with a 'border' condition, from where it can 'frame and foster a discussion of community and culture' and provide a view of the 'relation between institutionalised culture and participatory democracy' (Phillips 1995, p. 60). Likewise Rendell (2006, p. 4) suggests that public art has a possibility as a 'critical spatial practice' to 'work in relation to dominant ideologies but at the same time question them.' Chantal Mouffe $(2008, \mathrm{p} 13)$ situates the work of artists in public space as a crucial dimension to democracy, in that they 'disrupt the smooth image that corporate capitalism is trying to spread', they play an important role in subverting dominant hegemony, and they contribute to 'the construction of new subjectivities. This is an optimistic view in which short term, small, mainly ephemeral works that appear in public space are figuratively hurled against the larger and longitudinal visual proponents of public space -permanent bronze colonial statues, national war memorials, enlarged examples of high art by famous people, art married to architecture, and an ongoing visual stream (and now digital streaming) of billboard advertising.

Public art also highlights issues about the ownership, control of, and rights to public space. Any artwork outside the private home has to contend with a negotiation about how it is placed in that space. Whether commissioned, un-commissioned, intervention, paste up, stencil guerrilla kindness, throw ups, tagging, murals, ephemeral installations, yarn-bombing. Advertising imagery often has to negotiate its way in the space financially and has to be approved by authorities that have control over the space.

\section{Positive Action}

Whilst not negating public art and sculpture made by artists, it is useful to contemplate the types of narratives they offer. One of the narratives is that public art should be made by artists. What do public artworks where communities have been involved in the making, offer as an alternative? Primarily they offer a collaborative attitude to making historical objects. These works are evidence of people working together, and agreeing on a communal voice, or presenting many different voices. They also offer the possibility of the choice to represent individual community members and their ideas in public space. Examples of artworks made by community can include many voices such as the Great Wall of St Kilda, (St Kilda, 


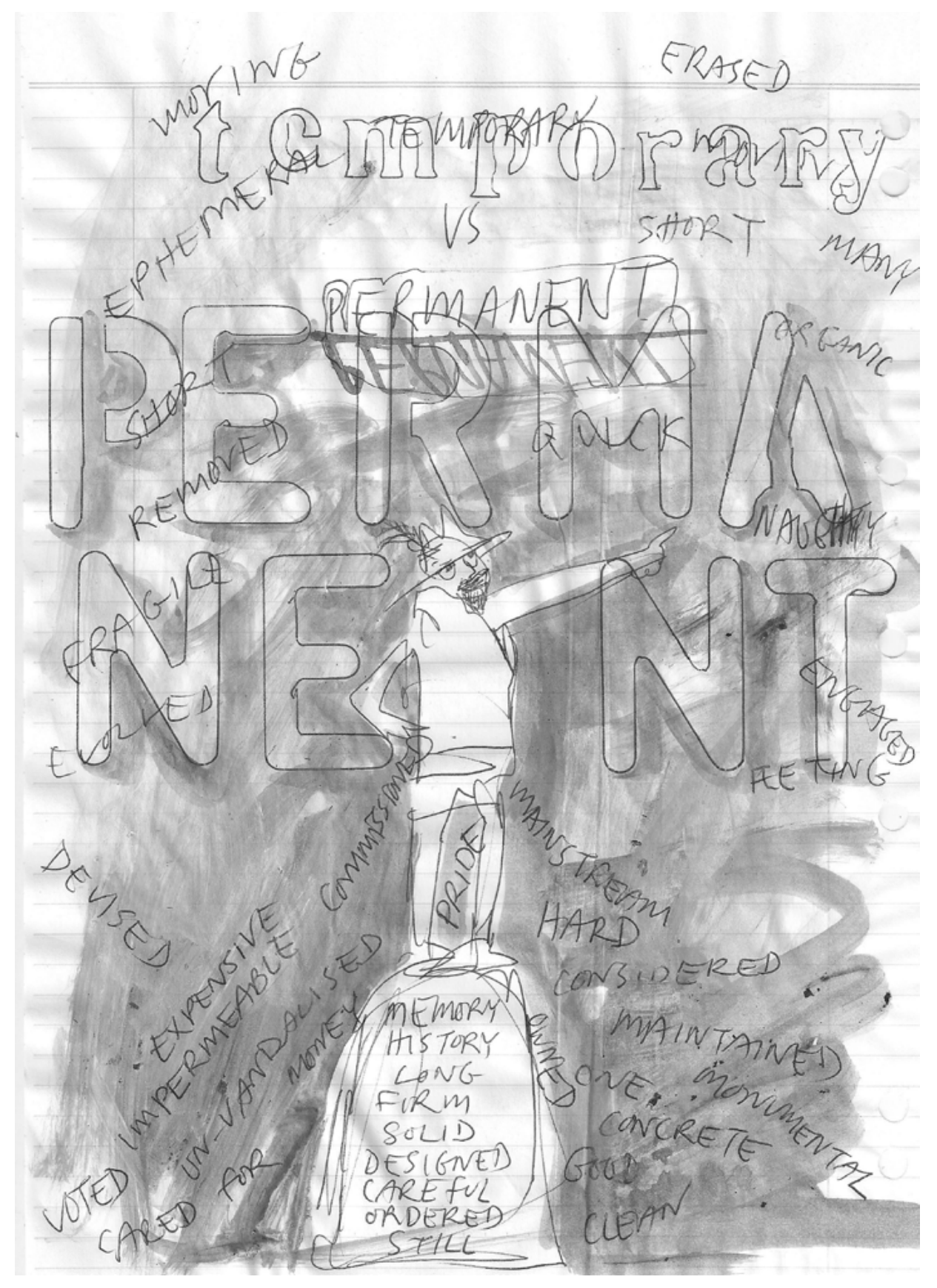

Figure 4: Temporary vs Permanent, Debbie Quadri, 2016.

Melbourne), the Great Wall of Los Angeles (North Hollywood, CA), the work of the Chicago Public Art Group, and the Belfast Murals. These artworks place importance on the ideas and contributions of local people in the meaning of the artwork, but also the exaltation of the ordinary citizen to the status of someone whose voice and creative efforts are important.

Likewise my approach to public pedagogy does not involve pointing out the way existing public art supports particular narratives, but instead takes a positive approach in a manner similar to Sara Lawrence-Lightfoot's search 'for what is good and healthy' (Lawrence-Lightfoot \& Hoffmann-Davis, p. 9). Furthermore, Schuermans et al. (2012, p. 677) deviate from the 'dominant analytical approach to public pedagogy... in focusing on the study of media, popular culture, and society as educative forces'. They draw from literature that aims at delib- 
erative active political interventions in society and emphasise that there is 'educational work' to be done in and for the public sphere.' They suggest they are 'encouraged to shift their focus from the artists and artworks per se toward the way audiences engage with art' (Schuermans et al. 2012, p. 677). Their theory stresses action in preference to analysing the past. I use the idea of public pedagogy as a vehicle to explain public art as a participant in expressing cultural knowledge. Its various genres converse or argue with each other. I see the permanent public artworks that I make with community members and writing about this genre of artwork, as the type of action that Schuermans et al. encourage.

The intent of this article has been to open up the ideas of public artworks as players in pedagogy. There is a need to balance the durational power of official public art with permanent participatory and collaborative works. These can offer other narratives and knowledge in public space. Considering the role art plays in public pedagogy, further research is warranted in the areas of community involvement as makers of permanent public art.

\section{Notes}

Many of the policy references in this article are Australian and this reflects my current research using three case studies located in Australia. This article is concerned with public art discourse within Western Culture, and particularly Australia. I feel that the issues that the article raises have something to contribute to the global discourse of public art, but also recognise the arguments are biased towards a very local experience and research site.

Community participation in making art has been theorised as part of the community arts movement in the 1960s-90s mainly across the USA, Canada, England, Ireland and Australia. Contributors to academic literature in this movement include; Gaye Hawkins, David Throsby, Kirby, Owen Kelly, Tony Bennet, Sandy Fitzgerald. Given the limited scope of this essay, this history and theory has not been explored here, but certainly has much to offer in terms of knowledge about what community participation is and does.

\section{Acknowledgment}

I would like to especially thank the referees who commented on my paper and directed me to further reading, considerations and revisions as I found them very useful. I would also like to acknowledge my PhD supervisors Dr Mark Selkrig and Professor Maureen Ryan who have contributed to the research journey that this paper emerged from.

\section{References}

Arnstein, S 1969, A ladder of Citizen Participation, Scotland Government Better Community Engagement Programme, Scotland.

Beyes, T 2010, 'Uncontained: The art and politics of reconfiguring urban space', Culture and Organization, Vol. 16, NO.3, pp. 229 - 246.

Bishop, C 2006, 'The social turn: Collaboration and its discontents', Artforum, Feb 2006, P $178-183$

Boros, D 2011, Creative Rebellion for the Twenty-first Century: The importance of public and interactive art to political life in America, Palgrave Macmillan. 
Bourriaud, N 2002, Relational Aesthetics, (trans) Simon Pleasance and Fronza Woods English Edition, les presses du reel, Paris.

Cartiere, C \& Willis, S 2008, The practice of public art, Routledge, NY.

Creative Victoria 2016, Department of economic development, jobs, transport and resources, State Governement of Victoria, viewed July 2016, http://creative.vic.gov.au/.

Crehan, K 2011, Community Art: an anthropological perspective, Berg, Oxford and New York.

Dawes, M 2008, 'Beyond Process: Art, Empowerment and sustainability', in Jokelo, T. \& Coutts, G (eds.) Art, Community and Environment: Educational Perspectives, Intellect Books, Chicago, Bristol UK.

de Certeau, M 1988, Practice of Everyday Life, Translated by: Rendall, S. Berkeley: University of California Press, CA.

Doherty, C 2015 Situations, viewed 9 October 2016, <http://www.situations.org.uk/ about/team/>.

Fazakerley, R 2008, 'Negotiating Public Space: Discourses of Public Art' PhD thesis, University of South Australia, Adelaide.

Finkelpearl, T 2000, Dialogues in Public art, USA: MIT Press, Cambridge, MA.

Gablik, S 1995, 'Connective Aesthetics: Art after Individualism', in Lacy, S (ed.) Mapping the Terrain: New Genre Public Art, Bay Press, Seattle, Washington, USA.

Gerin, A \& McLean, J S 2009, Public art in Canada: Critical Perspectives Toronto, University of Toronto Press, Toronto.

Halsey, M \& Young, A 2002, 'The meanings of graffiti and municipal administration', The Australian and New Zealand Journal of Criminology, 35(2), pp. 165-186.

Holsworth, M S 2015, Sculptures of Melbourne, Melbourne Books, Melbourne, VIC.

Jacob, M J 1995, 'An Unfashionable Audience', in Lacy, S. (ed.) Mapping the Terrain: New Genre Public Art, Bay Press, Seattle, Washington.

Kester, G 2005, 'Dialogical Aesthetics: A Critical Framework For Littoral Art', Variant, issue 9, Winter 1999/2000, viewed 9 October 2016 <http://www.variant.org.uk/pdfs/ issue9/Supplement9.pdf>

Lacy, S (ed.) 1995, Mapping the Terrain: New Genre Public Art, Bay Press, Seattle, Washington.

Landi, P J 2012, 'Public Art - Purpose and Benefits: Exploring strategy in the New England City of Pittsfield', Master of Landscape Architecture, University of Massachusetts, MA.

Hobart City Council, 2005, Hobart City Council Public Art Strategy, Hobart City Council.

Lawrence-Lightfoot, S \& Hoffmann-Davis, J 1997, The Art and Science of Portraiture, Josey-Bass, San Francisco, CA.

Melbourne City Council, 2015, About the Arts and Participation Program, viewed July 2016, <http://www.melbourne.vic.gov.au/AboutMelbourne/ArtsandEvents/ ArtsParticipation/Pages/AboutProgram.aspx>.

Miles, M 1997, Art, Space and the City, Routledge, London, New York. 
Mouffe, C 2008, 'Art and democracy: Art as an agonistic intervention in public space', Art as a public Issue, 14, pp. 6-13.

O'Neill, P 2010, 'Three stages in the art of public participation: The relational, social and durational', Eurozine, viewed 9 October 2016, < http://www.eurozine.com/ articles/2010-08-12-oneill-en.html>

Papastergiadis, N 2006, Spatial Aesthetics: Art, Place and the Everyday, Oram Press, Rivers, USA.

Phillips, PC 1995 'Public Constructions', in Lacy, S. (ed.) Mapping the Terrain, Bay Press, Seattle, Washington USA.

Pollock, VL \& Sharp, J 2012, 'Real Participation or the tyranny of participatory Practice? Public art and community involvement in the regeneration of the Raploch, Scotland', Urban Studies, (49 (14), pp. 3063-3079.

Rendell, J 2006, Art and Architecture: A place between, IB Tauris, London.

Sandlin, J A, O’Malley, M P \& Burdick, J 2015, 'Mapping the complexity of Public Pedagogy scholarship 1984 - 2010', Review of Educational Research, 81(3), pp. 338-375.

Schuermans, N, Loopmans, M P J \& Vandenabeele, J 2012, 'Public space, public art and public pedagogy', Social and Cultural Geography,13(7).

Sharp, J.2007, The life and death of five spaces: public art and community regeneration in Glascow, Cultural Geographies, 14, pp. 274-292.

Stage Two Report, Social impacts of participation in the arts and cultural activities, Department of Communications, Report commissioned by the Cultural Ministers Council's Statistics Working Group 2005, Commonwealth of Australia, Canberra.

\section{About the Author}

Debbie Qadri works as an artist mostly involving the making of permanent artworks with community groups such as schools but likes to describe herself as a troublemaker. She exhibits her own work under her maiden name of Debbie Harman. Debbie is currently undertaking $\mathrm{PhD}$ research at Victoria University in Melbourne on the topic of permanent public art made by community members. She is a member of the Institute of Public Pedagogies and Blacksmith Doris (a women's blacksmithing group).

debbieqadri@hotmail.com 